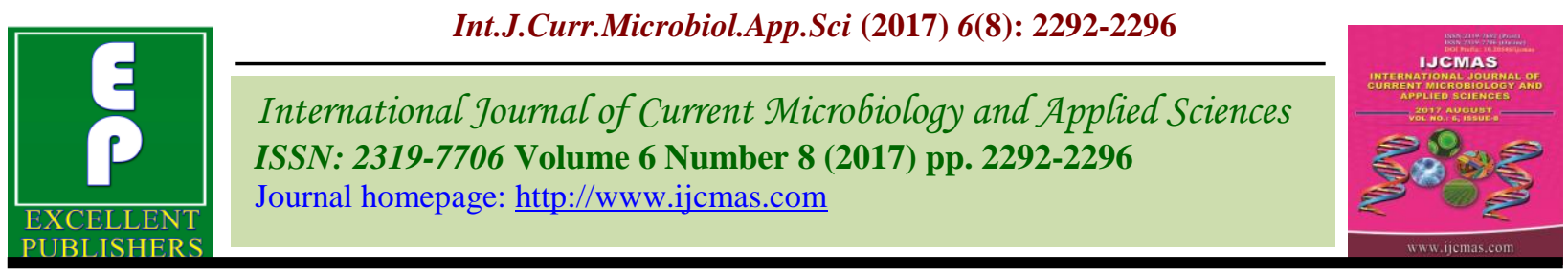

Original Research Article https://doi.org/10.20546/ijcmas.2017.608.269

\title{
Correlations among Grain yield and Yield attributes in Maize Hybrids as Influenced by Site Specific Nutrient Management (SSNM)
}

\author{
H.T. Chetan*, M.P. Potdar, B.T. Nadagouda, P.L. Patil and C.R. Patil \\ University of Agricultural Sciences, Dharwad, Karnataka, India \\ *Corresponding author
}

\section{A B S T R A C T}

Two maize hybrids (NK-6240 and 900 M GOLD) were compared for yield and yield components and correlations were worked out among the yield

Keywords

Hybrids, SSNM,

Target yield,

Correlation

co-efficient.

Article Info

Accepted:

21 June 2017

Available Online:

10 August 2017 parameters at various target yield levels in an experiment conducted at Mudhol Agricultural Research Station of University of Agricultural Sciences, Dharwad, Karnataka, during kharif 2014. The experiment was laid out in split plot design with three replications. 900 M GOLD with target yield of $140 \mathrm{q} \mathrm{ha}^{-1}\left(130.53 \mathrm{q} \mathrm{ha}^{-1}\right)$ recorded significantly higher grain yield over rest of the treatments. Correlation Co-efficient in maize revealed that grain yield of maize was positively correlated with yield components. Among yield components correlation of cob length $\left(0.993^{* *}\right)$ was significantly higher followed by cob girth $(0.974 * *)$. Based upon the correlations, cob length was also found a suitable marker for selecting a maize hybrid for higher grain yield along with other yield attributes i.e. cob girth, test weight and number of kernel rows $\operatorname{cob}^{-1}$.

\section{Introduction}

Maize is one of the most important cereal crops in India. It has gained importance only after wheat, rice and sorghum and also being called as most important industrial crop. It is consumed as both food and fodder. In India, about 35 per cent of the maize produced is used for human consumption, 25 per cent each in poultry and cattle feed production and 15 per cent in food processing industries like corn flakes, popcorn, starch, dextrose, corn syrup and corn oil.

The area under cultivation of maize in Karnataka is tremendously increased, which was 0.13 lakh hectares during 1960's to 1.35 million hectares during 2016. Further, it was recorded the production of 4.5 million tons and productivity of $33.85 \mathrm{q} \mathrm{ha}^{-1}$ (Anonymous, 2016). It is evident that food grain production has increased significantly due to chemical fertilizer consumption. Moreover, the present hike in prices of chemical fertilizers forced Indian farmers to resort to imbalanced nutrition and thus resulted in very poor yield per unit area. Judicious use of nutrients is one of the most important means to obtain higher yields. For efficient and economic use, it is necessary to have information on the optimum dose of nutrients and organics based on soil testing for different soils. Study on 
nutrient uptake by the crop and efficiency of added nutrients may help in formulating sound fertility evaluation programme. The current and generalized fertilizer recommendations which were developed decades ago were no longer valid and there is a need for site specific nutrient management which accommodates field-specific needs of crop for supplemental nutrient requirements.

The novel approach of SSNM involves science-based principles for guiding the judicious and efficient application of fertilizers as and when needed by crops. It recognizes the inherent spatial variability associated with fields during crop nutrients originating from soil, plant residues, manures and irrigation water. Thus, SSNM considers indigenous nutrient supply of the soil and productivity targets capable of sustaining higher yields on one hand, and assured restoration of soil fertility on the other. Gill et al., (2008) felt that with implementation of SSNM, the present food grain production could be achieved from half of the current irrigated area and rest could be better utilized in crop diversification efforts. production and provides guidelines for optimal use of indigenous Hence, present investigation was undertaken to study the correlation coefficient of growth and yield parameters of maize hybrids as influenced by site specific nutrient management.

\section{Materials and Methods}

A Field experiment was conducted during kharif 2014 at Mudhol Agricultural Research Station of University of Agricultural Sciences, Dharwad. It is located in Bagalkot district in the northern part of Karnataka State at $16^{\circ} 20$ " $\mathrm{N}$ latitude, $75^{\circ} 15^{\prime}$ E longitude and at an altitude of 577.6 meters above mean sea level. The soil of the experimental field was black vertisol with $\mathrm{pH}$ 7.95.The treatment combinations comprising two maize hybrids viz., NK-6240 and 900 M GOLD as main plot treatments and five target yield levels viz., $100,120,140 \mathrm{q} \mathrm{ha}^{-1}$, recommended dose of fertilizer (RDF) and absolute control as sub plot treatments. The RDF was $150-65-65 \mathrm{~N}$, $\mathrm{P}_{2} \mathrm{O}_{5}$ and $\mathrm{K}_{2} \mathrm{O} \mathrm{kg} \mathrm{ha}{ }^{-1}$. The experiment was laid out in split plot design with three replications. $10 \% \mathrm{~N}$ and entire dose of $\mathrm{P}_{2} \mathrm{O}_{5}$ and $\mathrm{K}_{2} \mathrm{O}$ was applied at the time of sowing in the form of urea, single super phosphate and muriate of potash respectively. Sowing of maize was done on $6^{\text {th }}$ August 2014 with a spacing of $60 \mathrm{~cm}$ between rows and $20 \mathrm{~cm}$ between plants. The remaining amount of nitrogen was applied in four split dosage at 25 DAS $(20 \% \mathrm{~N}), 35$ DAS $(30 \% \mathrm{~N}), 55$ DAS $(30 \% \mathrm{~N})$ and 65 DAS $(10 \% \mathrm{~N})$. All other recommended agronomic practices and plant protection measures was carried out to all treatments uniformly during the course of study. For calculating the coefficients of correlation, data of the mentioned parameters were averaged across the hybrids at various target yield levels and then coefficients of correlation were worked out among the mentioned parameters using excel worksheet (Gomez and Gomez, 1984).

\section{Results and Discussion}

\section{Grain yield (q ha $\left.{ }^{-1}\right)$}

Grain yield of maize was significantly influenced by maize hybrids. The maize hybrid 900 M GOLD (93.47 q ha ${ }^{-1}$ ) recorded significantly higher grain yield over NK-6240 $\left(91.81 \mathrm{q} \mathrm{ha}^{-1}\right)$. The increase in grain yield was to the extent of 1.77 per cent over NK-6240 hybrid. This might be due to genetic makeup and morphological characteristics of hybrids in exploiting climatic optima at important growth stages (Jemal Abdulai, 2010). Similar kinds of result have also been reported by Daikho (2013) and Singh et al., (2014). Among different target levels, significantly higher grain yield was recorded with target 
yield level of $140 \mathrm{q} \mathrm{ha}^{-1}\left(86.34 \mathrm{q} \mathrm{ha}^{-1}\right)$ over target yield of 100, $120 \mathrm{q} \mathrm{ha}^{-1}$, recommended dose of fertilizer (RDF) and absolute control. Significantly lower grain yield (19.01 q ha-1) was observed in absolute control. The increase in grain yield was 78.0 per cent over absolute control and 16.9, 7.7 and 39.8 per cent as compared to target yield levels of 100 , $120 \mathrm{q} \mathrm{ha}^{-1}$ and RDF respectively.

The higher grain maize was mainly due to better translocation of photosynthates from source to sink and higher growth attributing characters like higher number of leaves, leaf area and higher dry matter production and its accumulation into different parts of plant and yield attributing characters like cob length, cob girth, number of kernel rows per cob and test weight. The above result clearly indicates the importance of site specific application of nutrients required to achieve the targeted yields of maize. The increase in grain yield of maize was due to the application of higher level inorganic fertilizers. These results are in accordance with those obtained by Jayaprakash et al., (2006); Jemal Abdulai (2010); Biradar et al., (2013) and Pagad (2014). The interaction data on grain yield revealed that, $900 \mathrm{M}$ GOLD with target yield of $140 \mathrm{q} \mathrm{ha}^{-1}\left(130.53 \mathrm{q} \mathrm{ha}^{-1}\right)$ recorded significantly higher grain yield over rest of the treatments (Table 1). However, the lower grain yield was recorded in NK-6240 with absolute control (27.56 q ha $\left.{ }^{-1}\right)$.

Table.1 Grain yield $\left(\mathrm{q} \mathrm{ha}^{-1}\right)$ of maize hybrids as influenced by site specific nutrient management

\begin{tabular}{|c|c|}
\hline Treatments & Grain yield $\left(q\right.$ ha $\left.^{-1}\right)$ \\
\hline \multicolumn{2}{|l|}{ Hybrids (H) } \\
\hline $\mathrm{H}_{1}-\mathrm{NK} 6240$ & 91.81 \\
\hline $\mathrm{H}_{2}-900 \mathrm{M}$ GOLD & 93.47 \\
\hline S.Em \pm & 0.11 \\
\hline $\mathrm{CD}(0.05)$ & 0.64 \\
\hline \multicolumn{2}{|l|}{ Target yields $\left(\mathrm{q} \mathrm{ha}^{-1}\right)(\mathrm{T})$} \\
\hline $\mathrm{T}_{1}$ - Target yield $100 \mathrm{q} \mathrm{ha}^{-1}$ & 71.75 \\
\hline $\mathrm{T}_{2}$ - Target yield $120 \mathrm{q} \mathrm{ha}^{-1}$ & 79.70 \\
\hline $\mathrm{T}_{3}$ - Target yield $140 \mathrm{q} \mathrm{ha}^{-1}$ & 86.34 \\
\hline $\mathrm{T}_{4}-\mathrm{RDF}$ & 52.00 \\
\hline $\mathrm{T}_{5}$ - Absolute control & 19.01 \\
\hline S.Em \pm & 0.24 \\
\hline $\mathrm{CD}(0.05)$ & 0.72 \\
\hline \multicolumn{2}{|l|}{ Interactions $(\mathbf{H} \times \mathbf{T})$} \\
\hline $\mathrm{H}_{1} \mathrm{~T}_{1}$ & 106.35 \\
\hline $\mathrm{H}_{1} \mathrm{~T}_{2}$ & 119.27 \\
\hline $\mathrm{H}_{1} \mathrm{~T}_{3}$ & 128.49 \\
\hline $\mathrm{H}_{1} \mathrm{~T}_{4}$ & 77.39 \\
\hline $\mathrm{H}_{1} \mathrm{~T}_{5}$ & 27.56 \\
\hline $\mathrm{H}_{2} \mathrm{~T}_{1}$ & 108.90 \\
\hline $\mathrm{H}_{2} \mathrm{~T}_{2}$ & 119.82 \\
\hline $\mathrm{H}_{2} \mathrm{~T}_{3}$ & 130.53 \\
\hline $\mathrm{H}_{2} \mathrm{~T}_{4}$ & 78.62 \\
\hline $\mathrm{H}_{2} \mathrm{~T}_{5}$ & 29.46 \\
\hline S.Em \pm & 0.34 \\
\hline $\mathrm{CD}(0.05)$ & 0.72 \\
\hline
\end{tabular}

$\mathrm{T}_{1}$ : 288.0:89.0:67.2 N, $\mathrm{P}_{2} \mathrm{O}_{5}$ and $\mathrm{K}_{2} \mathrm{O} \mathrm{kg} \mathrm{ha}{ }^{-1}, \mathrm{~T}_{2}: 345.6: 106.8: 80.6 \mathrm{~N}, \mathrm{P}_{2} \mathrm{O}_{5}$ and $\mathrm{K}_{2} \mathrm{O} \mathrm{kg} \mathrm{ha}{ }^{-1}, \mathrm{~T}_{3}$ : 403.2:124.6:94.0 N, $\mathrm{P}_{2} \mathrm{O}_{5}$ and $\mathrm{K}_{2} \mathrm{O} \mathrm{kg} \mathrm{ha}{ }^{-1}, \mathrm{~T}_{4}:$ 150.0:65.0:65.0 N, $\mathrm{P}_{2} \mathrm{O}_{5}$ and $\mathrm{K}_{2} \mathrm{O}$ kg ha ${ }^{-1}$ 
Table. 2 Correlation coefficient (r), grain yield $\left(\mathrm{q} \mathrm{ha}^{-1}\right)$ and yield parameter as influenced by site specific nutrient management

\begin{tabular}{|l|c|c|c|c|c|c|c|}
\hline \multicolumn{1}{|c|}{ Parameters } & $\begin{array}{c}\text { Grain } \\
\text { yield }\end{array}$ & Cob length & Cob girth & $\begin{array}{c}\text { No. of kernel } \\
\text { rows cob }^{-1}\end{array}$ & $\begin{array}{c}\text { No. of } \\
\text { kernels } \\
\text { row }^{-1}\end{array}$ & $\begin{array}{c}\text { No. of } \\
\text { kernels }_{\text {cob }^{-1}}\end{array}$ & $\begin{array}{c}\text { Kernel } \\
\text { weight }_{\text {cob }^{-1}}\end{array}$ \\
\hline Cob length & $0.993^{* *}$ & --- & --- & --- & --- & --- & --- \\
\hline Cob girth & $0.974^{* *}$ & $0.981^{* *}$ & --- & --- & --- & --- & --- \\
\hline $\begin{array}{l}\text { No of kernel } \\
\text { rows cob }\end{array}$ & $0.953^{* *}$ & $0.954^{* *}$ & $0.960^{* *}$ & --- & --- & --- & --- \\
\hline $\begin{array}{l}\text { No of kernels } \\
\text { row }^{-1}\end{array}$ & $0.892^{* *}$ & $0.900^{* *}$ & $0.943^{* *}$ & $0.945^{* *}$ & --- & --- & --- \\
\hline $\begin{array}{l}\text { No of kernels } \\
\text { cob }^{-1}\end{array}$ & $0.893^{* *}$ & $0.902^{* *}$ & $0.944^{* *}$ & $0.959^{* *}$ & $0.992^{* *}$ & --- & --- \\
\hline $\begin{array}{l}\text { Kernel weight } \\
\text { cob }^{-1}\end{array}$ & $0.936^{* *}$ & $0.951^{* *}$ & $0.973^{* *}$ & $0.968^{* *}$ & $0.958^{* *}$ & $0.978^{* *}$ & --- \\
\hline Test weight & $0.946^{* *}$ & $0.948^{* *}$ & $0.904^{* *}$ & $0.851^{* *}$ & $0.747^{* *}$ & $0.771^{* *}$ & $0.873^{* *}$ \\
\hline
\end{tabular}

$* *=$ Highly significant $(\mathrm{P}=0.01)$

Correlations among yields, yield components of maize hybrids

It was observed that grains yield showed positive and highly significant $(\mathrm{P}=0.01)$ correlation with cob length $\left(\mathrm{r}=0.993^{* *}\right)$, cob girth $(r=0.974 * *)$, number of kernel rows $\operatorname{cob}^{-1}\left(\mathrm{r}=0.953^{* *}\right)$, number of kernels $\operatorname{row}^{-1}(\mathrm{r}$ $\left.=0.892^{* *}\right)$, number of kernels $\operatorname{cob}^{-1}(\mathrm{r}=$ $\left.0.893^{* *}\right)$, kernel weight $\operatorname{cob}^{-1}\left(\mathrm{r}=0.936^{* *}\right)$ and test weight $\left(\mathrm{r}=0.946^{* *}\right)$ (Table 2). Cob length showed positive and highly significant $(\mathrm{P}=0.01)$ correlation with cob girth $(\mathrm{r}=$ $\left.0.981^{* *}\right)$, number of kernel rows $\operatorname{cob}^{-1}(\mathrm{r}=$ $0.954 * *)$, number of kernels $\operatorname{row}^{-1}(\mathrm{r}=$ $\left.0.900^{* *}\right)$, number of kernels $\operatorname{cob}^{-1}(\mathrm{r}=$ $\left.0.902^{* *}\right)$, kernel weight $\operatorname{cob}^{-1}\left(\mathrm{r}=0.951^{* *}\right)$ and test weight $\left(\mathrm{r}=0.948^{* *}\right)$. Cob girth showed positive and highly significant $(\mathrm{P}=0.01)$ correlation with number of kernel rows $\operatorname{cob}^{-1}\left(\mathrm{r}=0.960^{* *}\right)$, number of kernels $\operatorname{row}^{-1}\left(r=0.943^{* *}\right)$, number of kernels $\operatorname{cob}^{-1}(r$ $\left.=0.944^{* *}\right)$, kernel weight $\operatorname{cob}^{-1}\left(\mathrm{r}=0.973^{* *}\right)$ and test weight $\left(\mathrm{r}=0.904^{* *}\right)$. Number of kernel rows $\mathrm{cob}^{-1}$ showed positive and highly significant $(\mathrm{P}=0.01)$ correlation with number of kernels $\operatorname{row}^{-1}\left(\mathrm{r}=0.945^{* *}\right)$, number of kernels $\operatorname{cob}^{-1}\left(\mathrm{r}=0.959^{* *}\right)$, kernel weight $\operatorname{cob}^{-1}$ $\left(\mathrm{r}=0.968^{* *}\right)$ and test weight $\left(\mathrm{r}=0.851^{* *}\right)$. Number of kernels row ${ }^{-1}$ showed positive and highly significant $(\mathrm{P}=0.01)$ correlation with number of kernels $\operatorname{cob}^{-1}(\mathrm{r}=0.992 * *)$, kernel weight $\operatorname{cob}^{-1}\left(r=0.958^{* *}\right)$ and test weight $(r=$ $\left.0.747^{* *}\right)$. Number of kernels $\mathrm{cob}^{-1}$ showed positive and highly significant $(\mathrm{P}=0.01)$ correlation with kernel weight $\operatorname{cob}^{-1}(\mathrm{r}=$ $\left.0.978^{* *}\right)$ and test weight $\left(\mathrm{r}=0.771^{* *}\right)$. Wajid et al., (2007); Rafique et al., (2004); Vasic et al., (2001) and Jemal Abdulai (2010) reported positive correlations (P 0.01) among yield, yield components.

\section{References}

Anonymous, 2016. www.indiastat.com

Biradar, A., Jayadeva, H. M., Shankarlingappa, B. C. and Vishwanath, A. P. 2013. Effect of target yield approach on growth, yield and nutrient uptake at flowering of maize. Mysore J. Agric. Sci., 47(4): 707-712.

Daikho, A. 2013. Performance of maize hybrids to varying fertilizer levels in the northern transitional zone of Karnataka. M. Sc. (Agri.) Thesis, Univ. Agric. Sci., Dharwad, Karnataka (India).

Gill, M. S., Shukla, A. K. and Pandey, P. S. 2008. Yield, nutrient response and economic analysis of important cropping systems in India. Indian $J$. 
Fert., 4(4): 11-38.

Gomez, K.A. and Gomez, A. A. 1984. Statistical Procedures for Agric. Research. $2^{\text {nd }}$ ed. John Wiley \& Sons, Inc., USA.

Jayaprakash, T. C., Nagalikar, V. P., Pujari, B. T. and Shetty, R. A. 2006. Effect of organics and inorganics on growth and yield of maize under irrigation. Karnataka J. Agric. Sci., 18(3): 798.

Jemal Abdulai, 2010. Response of maize (Zea mays L.) and chickpea (Cicer arietinum L.) to site specific nutrient management (SSNM) through targeted yield approach, M. Sc (Agri.) Thesis Univ. Agric. Sci., Dharwad, Karnataka (India).

Rafique, M., Hussain, A., Mahmood, T., Alvi,
A. W. and Alvi, M. B. 2004 Heritability and interrelationships among grain yield and yield components in maize (Zea mays L.). Int'l. J. Agric. \& Biol. 6(6): 1113-1114.

Vasic, N., Ivanovic, M., Peternelli, L. A., Jockovic, D., Stojakovic, M. and Bocanski, J. 2001. Genetic relationship between grain yield and yield components in a synthetic maize population and their implications in selection. Acta Agronomica Hungarica. 49(4): 337-342.

Wajid, A., Ghaffar, A., Maqsood, M., Hussain, K. and Nasim, W. 2007. Yield response of maize hybrids to varying nitrogen rates. Pak. J. Agric. Sci. 44(2): 217-220.

\section{How to cite this article:}

Chetan, H.T., M.P. Potdar, B.T. Nadagouda, P.L. Patil and Patil, C.R. 2017. Correlations among Grain yield and Yield attributes in Maize Hybrids as Influenced by Site Specific Nutrient Management (SSNM). Int.J.Curr.Microbiol.App.Sci. 6(8): 2292-2296. doi: https://doi.org/10.20546/ijcmas.2017.608.269 